\title{
Blusukan Cultural as a Political Power in The Regional Head Election of Surakarta
}

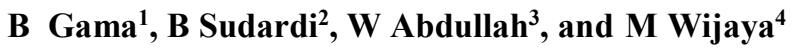 \\ ${ }^{1}$ Candidate Doctor of Cultural Studies at Universitas Sebelas Maret, Surakarta, Indonesia, \\ Lecturer of Universitas Veteran Bangun Nusantara Sukoharjo, Indonesia \\ 234 Universitas Sebelas Maret Surakarta, Indonesia \\ E-mail: bettygama_62@ymail.com
}

\begin{abstract}
Blusukan has existed since the days of the Javanese kings. In the context of political communication, the blusukan carried out by political candidates aims to influence the voice of potential voters or to win the campaign. Attire, ways of speaking, language, posture and other attributes used by political candidates determine people's perception of the candidate's image. In order to attract public attention, political candidates use local cultural identities and attributes, namely Javanese culture to various places. Although we have entered the era of digital technology, but the strength of blusukan can still be felt today through the interpersonal communication between political candidates and the society. This research uses literature study method and documentation study from credible and reliable data. The data collected consists of two types, for instance primary and secondary data.Qualitative analysis is carried out in desk study, namely information retrieval and data collection through literature studies. The results showed: the society felt proud to be able to meet directly with the political candidates, blusukan had been able to influence the behavior of potential voters, and blusukan was very effective during the regional head election campaign.
\end{abstract}

Keywords: Blusukan, Cultural Javanese; Pilkada; Javanese Language

\section{INTRODUCTION}

As happened in Surakarta City, the residents still closely holds Javanese cultural traditions. Therefore, when conducting election campaigns, the aspects related to Javanese cultural traditions are one of the decisive factors in order to win political actors. According Ton [1] The election is essentially people's democratic parties, in which people in each region can vote free and secret who the governors, regents or mayors will be their leaders. The regional head election (Pilkada) is one step forward in realizing democracy at the local level, how the regional head candidates are able to influence and win the hearts of the people. The regional head election is 
an important indicator to see the change in a political society that happened in Surakarta City. One attempt to get the biggest voice in the election campaign is to do blusukan.

Blusukan began to be known to the people of Surakarta in 2005, when Joko Widodo (Jokowi) with his partner FX Hadi Rudyatmo has won the election of Mayor and Deputy Mayor of Surakarta City period 2005-2010. Blusukan also cannot be separated from the use of Javanese cultural identity, such as the use lurik clothes (Javanese attire), batik clothes, blangkon (hat), language and andhap asor (attitude of respect). According to [2], ethnic identity is characterized by their cultural, linguistic, organizational and ideological symbols. Each ethnic has an identity that must be obeyed by the society, in order to interact with each other.

Although the era has entered the digital era, but the strength of blusukan still can be felt up to now. Blusukan has been done by the candidate with the intent, first, to introduce themselves to the public; second, conveying vision and mission; third, influencing the society to be willing to vote for the candidate and fourth, to deliver political promises. The actual blusukan strategy also shows a close interpersonal communication pattern between the candidate and the community without any obstacles.

\section{METHOD}

This research uses qualitative method, literature study, and documentation study of credible and reliable data. Furthermore, these data are grouped in primary and secondary data. This type of research uses the critical paradigm that refers to Norman Fairclough's Critical Discourse Analysis (CDA). Fairclough offers three dimensions of discourse, namely text, discourse practice and sociocultural practice. The object of research is news about the blusukan cultural carried out by political actor candidates in the regional head election of Surakarta 2010 in Solopos newspaper.

\section{RESULT AND DISCUSSION}

\subsection{Blusukan Culture}

Blusukan comes from the Javanese language etymologically, from the basic word blusuk (means entrance) and the suffix -an (affix verb) which means entering into a certain place to know something. The term blusukan refers to the behavior of wandering in and out to a place, just to recognize the condition of a place naturally or culturally. Blusukan is a term of someone's expression, which travels to 'problem' places that have not yet been revealed. The term blusukan can not be separated from Surakarta King, namely King Paku Buwono V. The story of King Paku Buwono V's blusukan is written in a book with title "Pakoeboewono V" by Soemosapoetro in 1956. In the book "Pakoeboewono V" is told that he King Paku Buwono V was sad, because his kingdom was in a food crisis. Under these difficult circumstances, King Paku Buwono V received information that there were officials in his area, who stockpiled food in the times of crisis. King Paku Buwono V has determined to investigate the issue, "anjajah desa milang kori",which means to wander around the region by masquerading as ordinary people (incognito). King Paku Buwono V wants to prove directly "laku nggunting dalam lipatan" about the actions of his subordinates. When arrived at the destination named Keduwang Village, Gunung Kidul, which at that time was an administrative of Surakarta territory, the king of Surakarta was stunned, while watching his people are queuing to buy rice in the house of region's leader called Demang Keduwang. Apparently Demang Keduwang was a wealthy 
official and has a lot of rice barns. However, Demang Keduwang was a stingy and willing to sell rice to his own people at high prices. In the evening, King Paku Buwono V visited Keduwang Demang's house and received an unpleasant reception from Demang Keduwang.

The other Javanese kings who performed blusukan were Prince Sambernyowo and Sri Sultan Hamengkubuwono from Yogyakarta. Prince Sambernyowo or Duke of Mangkunegoro I has one principle, the people are water, we live in the water of the people, if the leader is clean, then the water is also clear. Prince Sambernyowo according to the book of "Babad Mangkunegaran", which is a diary of Mangkunegoro I, tells that every Wednesday Legi in the first week and Thursday Pahing in the third week, Mangkunegoro I do blusukan, see the people's daily life. Besides Mangkunegoro, Besides Mangkunegoro, the most famous Javanese king did blusukan named Sri Sultan Hamengkubuwono IX (1940-1988). One that makes him popular is his people's spirit [3]. The Sultan Hamengkubuwono IX had done blusukan by visiting people's posts, people's stalls, in the middle of Yogyakarta's rice fields, hearing what the people of Yogyakarta wanted.

If blusukan already existed since the era of the Kings, then after the era of Indonesian independence blusukan also made by several presidents, for instance Ir. Soekarno, Soeharto, Susilo Bambang Yudhoyono, and Jokowi. The first President of the Republic of Indonesia Ir. Soekarno had done blusukan by asking the villagers, chatting, recording and feeling how the people's lives and other daily life problems. The second President of the Republic of Indonesia Soeharto often carried out blusukan activities, especially in the early days of his administration to see first hand the condition of the people. At the time of the blusukan activity, Soeharto had incognito or disguised him to an isolated area to see the results of development, sleep in the house of a resident or village head. The sixth President of the Republic of Indonesia Susilo Bambang Yudhoyono also conducted blusukan using the term turba (abbreviation: down to earth). Blusukan has been carried out by political actors by going to a particular area, for instance the traditional market. This has been done by political actors, in order to find out the problems that exist in a particular location. In the context of political communication, in the lead up of the regional election, blusukan is better known as a form of introducing political actors to the society directly. This interpersonal communication is used by political actors in the regional head election, in order to introduce themselves or convey the vision of mission, work program, promises, and so forth to win the campaign. In the election of Surakarta City that have been done three times $(2005,2010,2015)$, all political actors use local cultural identity to attract the people's attention. Self-identification as part of the local ethnic or vice versa as ethnic immigrants is very important in the context of local politics today. Ethnic symbols and attributes are the differentiator for anyone in the social interaction, including in how one undergoes political roles [4]. The activity of political communication as the key to success in achieving success in political role, of course, must use the ethnic identity to expand public acceptance.

Self-identity is related to local identity, when a political actor campaigns through blusukan activity to various places. This identity equation makes the people's appeal to make choices. The same attire, language, and behavior awaken the emotions of the electorate to support the political actors. As Jokowi, a Surakarta mayoral candidate with his distinctive style, succeeded in influencing Surakarta residents in the 2005 regional head election. Blusukan cultural is one of the political forces to win the presidential election or regional head election, as was done by Jokowi. Below is a table of vote acquisition, when Jokowi is running in the Surakarta City regional election in 2010 . 
Table 1. Regional Election Votes

\begin{tabular}{cccc}
\hline Candidate Name & Party & Voice & \% \\
\hline Joko Widodo - F.X. Hadi Rudyatmo & PDIP & 248.243 & $90.09 \%$ \\
Eddy Wirabhumi - Supradi & PD, Golkar, & 27.306 & $9.91 \%$ \\
Kertamenawi & Hanura & & \\
\hline
\end{tabular}

The implementation of Surakarta City election is also not separated from the cultural identity of Surakarta City and the campaign attributes used by the couple of political actors also represent the cultural identity of Surakarta City. Through blusukan that has been done by political actors, the society can meet face to face with candidates, interact, and so forth. Blusukan cultural as a form of political campaign can encourage voter participation. Candidates for regional heads and political parties should intensively sell themselves, so the public will judge that they are eligible to be elected. The image, integrity, program offered and track record are the most important selling item to boost voter participation [5]. In the basic stage, the branding of politicians is shaped from the subjective understanding of society towards politicians. Not only the personal elements of a candidate, but also the candidate elements, in terms of appearances such as hairstyles, outfit give a clear impact to the image of the candidate [6]

\subsection{Attire}

Attire shows the identity of an area or nation, because it is a cultural object of a particular society. Typical regional attire such as lurik clothes is used during the campaigns to attract public sympathizers. This attire is a physical manifestation of ideas, values, and norms that govern and give direction to society in a particular culture. Fashion and attire is a form of nonverbal communication, where it does not use spoken or written words [7] Lurik according to the National Encyclopedia of Indonesia (1997) is a yarn woven fabric originating from the Central Java region, which has the basic motif of stripes or boxes with gloomy colors, which are generally interspersed with various colors of yarn. The word lurik comes from the root word rik which means a line or a ditch is interpreted as a fence or protector for the wearer. The lurik fabric is a symbol because it has meaning. Geertz [8] says symbols are signs that can be interpreted or explained. The meaning is something that is invisible but can be seen through interpretations and insights, which are then arranged in such a way.

At the time of the 2015 regional election campaign, Mr. FX Hadi Rudyatmo- Mr. Achmad Purnomo used lurik clothes and caping (hats). These outfits are then the official uniforms that used in the letter of voting and campaign tools. According to FX Hadi Rudyatmo, a circular and conical caping (hat) means to always remember God in taking responsibility. This caping hat as a symbol of hard work for the society [9]. The lurik clothes are also used by aa pair of candidate Jokowi-FX Hadi Rudyatmo in the regional election 2010. These clothes are used by Jokowi-Rudy, when they register as mayor and vice mayor at the Election Commission (KPU) of Surakarta City. The Solopos newspaper in one of its stories presents the title (March 4th, 2010): The Registration Procession Conducted Festive Like a Bride, Jokowi-Rudy paraded Towards General Election Commissions (KPU).

Registration of candidate pair of regional head Joko Widodo - FX Hadi Rudyatmo for the Regional Head Election (Pilkada) 2010, took place lively. Wrapped in the nuance of Javanese custom, the candidate pair used lurik motives attire and black headbands, headed 
for the KPU Secretariat Office at the Manahan Stadium complex. While their supporters, from coalition partners have joined along with the incumbent pair.

In Manahan complex, they are greeted by traditional dances and art of Reog. Before entering the KPU Secretariat Office, like a pair of Javanese bride, first performed a procession of pasrah tinampi, right in front of the KPU Secretariat Office of Surakarta City. Using the karma inggil language, a speaker hand over the candidate pair to YF Soekasno, to be registered as a candidate pair of mayor and deputy mayor.

Beside lurik clothes, there is still more typical cultural attire of Solo City, namely batik.Batik clothes with godhong kates motive used by the couple Jokowi - FX Hadi Rudyatmo on the campaign elections of Surakarta City in 2010. Godhong kates or papaya leaves since ancient times known as raw materials of herbs (jamu) that have a bitter taste, but give extraordinary health effects. Godhong kates batikworn by the pair candidate of JokowiRudy as branding campaign in the regional head election. Godhong kates batik is very eye catching outfit. Easy to see and easy to recognize.Something that illustrates optimism among voters[10].

The expression of identity through clothing worn by someone aims to achieve a political goal, which is an attribute that is artificial. It is a form of front stage management. The parts of the appearance on the front stage are a form of self-image maintenance, in order to be stable in front of audiences. Herbert Mead in [11] says that human interaction uses symbols, how to use symbols present what they mean to communicate with each other. The motive of godhong kates batik clothes as an icon is part of Jokowi-Rudy campaign, because they want to be different and at the same time want to promote Surakarta local product. In the news lead of Solopos newspaper explains, "The motive of godhong kates batik clothes (papaya leaves batik) is so attached to the figure of mayor candidate Joko Widodo and the deputy mayor FX Hadi Rudyatmo [10].

\subsection{Interpersonal Communication}

Blusions carried out during the Pilkada campaign are intended to try to find out what is happening on the ground, build trust and closeness in order to get potential voters. Blusukan is an action taken by someone to get to know and know the real conditions in the field [12]. This can be done through interpersonal communication between candidates and the community so as to increase public trust. Through interpersonal communication, the public can see directly the candidate's profile such as body shape, clothing, speech style, language used, attributes used and so on. Blusukan done in slums or areas that contain problems and densely populated often also used by local residents to ask for direct assistance. This was experienced by Joko Widodo during a blusukan in the Margorejo area, near the Balapan station. An old woman said: "Mr. Jokowi, my desk for selling is broken. Please ask for a table, " with a sad face [13]. Blusukan became a new culture that was carried out by candidates for mayors and deputy mayors ahead of the elections. As one form of socialization to introduce oneself to the community, blusukan is more seen as part of imaging. Blusukan politics is done so that it looks concerned with the problems found in the community, listens to complaints and helps solve problems.

Blusukan has been done since the era of kingdom, but blusukan carried out during the presidential election or regional election campaign, it has a tremendous power that can affect the voter behavior. One of the contributing factors is that there are political promises delivered 
by the political candidate, if he/she is elected as the winner of the regional election and the society will support him/her, if the promise is profitable. In the theory of social exchange found by George $\mathrm{C}$ Homans, he explained that in a social relationship there are elements of reciprocity, rewards or consideration as well as mutual benefits. According to Ritzer [14], Homans theory departs from the basic economic assumptions (rational choice) that individuals give what and get what, whether favorable or not. Blusukan as a political force is not just a gathering between political candidates with the society, but also contains political content as a strategy to win the regional election

\section{CONCLUSION}

Blusukan is one form of interpersonal communication between political candidates and the society. The face-to-face meeting has made people proud because not all political figures or public officials are willing to meet with the lower classes. Through the dialogue there are spoken words, promises and expectations conveyed by the candidate. As one form of election campaign, blusukan is expected to influence voters. When the election campaign of Surakarta City, Joko Widodo has done blusukan cultural activity, which has great potential to influence voter participation. The identity of Javanese culture, for instance language, clothes, attitudes, behavior and other attributes attached to the candidate have made the society in a homophylus condition. The existence of this identity equation has made the society voluntarily vote for the candidate. Blusukan cultural has proven very effective during the campaign of Presidential Election (Pilpres) and the regional head election (Pilkada). Through blusukan, political candidates or actors can introduce themselves to the society, convey vision and mission, influence the community to be willing to vote according to their own desires and to give political promises as a form of candidate self-image.

\section{REFERENCES}

[1] Amirudin and A. Z. Basri, Pilkada Langsung: Problem dan Prospek. Yogyakarta: Pustaka Pelajar, 2006.

[2] T. H. Eriksen, Ethnicity and nationalism: Anthropological perspectives. Sterling, VA: Pluto Press, 2015.

[3] A. D. Nugrahanto, "Blusukan Dalam Sejarah: Dari Sambernyawa sampai Jokowi," Kompasiana, 2015.2 [Online]. Available: https://www.kompasiana.com/anton_djakarta/552a6008f17e61 f003d623a6/blusukandalam-sejarah-dari-sambernyawa-sampai-jokowi. [Accessed: 16-Dec-2018].

[4] I. Lampe, "Identitas Etnik dalam Komunikasi Politik," J. Ilmu Komun., vol. 8, no. 3, pp. 299-313, 2010.

[5] Solopos, "Partisipasi Pemilih dan Legitimasi," 2018.

[6] B. Mitsikopoulou, "Introduction: the branding of political entities as discursive practice.," J. Lang. Polit., vol. 7, no. 3, pp. 353-371, 2008.

[7] M. Barnard, Fashion as Communication. London and New York: Routledge, 2013.

[8] F. Anggraeni, "Lurik, Dari Masa ke Masa," ARTISTA, vol. 10, no. 1, 2007.

[9] Daryono, "Rudy Berlurik, Anung Pilih Baju Putih,” Suara Merdeka, 2015. [Online]. 
Available: http://www.iklansuaramerdeka.com/rudy-berlurik-anung-pilih-baju-putih/. [Accessed: 14-Dec-2018].

[10] T. S. Arum and A. Prawitasari., "Batik Godhong Kates di Balik Kesuksesan Jo-Dy...," 2010.

[11] S. Dilla, "Simbolisasi Etnik Muna di Bandung: Studi Identitas Etnik Orang Muna," Mediat. (Jurnal Komunikasi), vol. 9, no. 2, pp. 317-326, 2008.

[12] N. Khaerah and A. P. Kesmawan., "Blasukan Sebagai New Cultural Komunikasi Politik Pada Pilkada Serentak 2015 Di Indonesia," in Prosiding Seminar Nasional Pilkada Serentak, 2015.

[13] “Politik Uang Bisa Membuat Solo Rusuh," Suara Merdeka.

[14] G. Ritzer and D. J. Goodman, Teori Sosiologi Modern. Jakarta: Kencana, 2008. 